\title{
References:
}

HENZELMANN, M. (ed.): Linguistik als diskursive Schnittstelle zwischen Recht, Politik und Konflikt. Hamburg: Verlag Dr. Kovač, 2018. 315 S. Studien zur Slavistik, Band 42. ISBN 978-3-8300-9459-3.

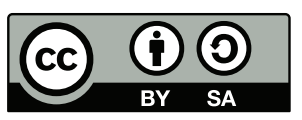

This work can be used in accordance with the Creative Commons BY-SA 4.0 International license terms and conditions (<https://creativecommons.org/licenses/by-sa/4.0/legalcode>). This does not apply to works or elements (such as images or photographs) that are used in the work under a contractual license or exception or limitation to relevant rights.

https://doi.org/10.5817/OS2020-2-7

\section{Словарь par excellence - исторически первый в контексте словацкой русистики}

GRIGORJANOVÁ, T. - GAJARSKÝ, L.: Slovník rusko-slovenských medzijazykových homoným. Brno: Tribun EU, 2019. 127 s. ISBN 978-80-263-1544-5.

Проблема межъязыковой омонимии, как одной из наиболее сложных задач языкового исследования, возникает в тесной связи с глобализацией общения. Активизация интерференции лексических и семантических заимствований является наглядным примером воздействия этого процесса, который затрагивает все сферы жизни, включая язык.

Сравнительное изучение межъязыковой омонимии связано с другими важными теоретическими проблемами лингвистики, включая широко распространённый билингвизм, полилингвализм и языковые контакты на синхронной основе.

В настоящее время в лингвистике проблема межъязыковых омонимов (точно так же в прошлом слова разных языков, которые имели одинаковую внешнюю форму, но разные значения, привлекали внимание лингвистов) адекватно решается и изучается не только на генетически родственных языках ${ }^{1}$. Можно

1 См., напр.: LOTKO, E.: Zrádná slova v polštině a češtině. Olomouc: Filozofická fakulta Univerzity Palackého, 1987; BARTÁKOVÁ, J.: K zradnostiam v blizkopríbuzných jazykoch. In: ŠLOSAR, D. (red.): Sborník prací Filozofické fakulty brněnské univerzity. Brno: Masarykova univerzita, 1998, s. 151-159; HORÁKOVÁ, R.: Medzijazyková homonymia pri geneticky príbuzných jazykoch. Filologická revue, roč. 2, 1999, č. 4, s. 52-56; HORÁKOVÁ, R.: Slovinsko-slovenská homonymia z konfrontačného hladiska. In: PANČÍKOVÁ, M. (ed.): Philologica LIII. Zborník Filozofickej fakulty Univerzity Komenského v Bratislave, 2001, s. 175-180; HORÁKOVÁ, R.: Interlingválne homonymá ako lexikografický problém. 
предположить, что ложные слова между родственными языками (например, словацкий - русский) работают по-другому, и иначе работают в генетически разных языках (например, словацкий - английский).

Из дидактической и переводческой практики мы также знаем, что при работе с близкородственными и несвязанными (неродственными) языками существует положительный перенос (транспозиция) между средствами выражения этих языков (обогащение языкового словаря новыми корнями, словообразовательными элементами и терминами) и отрицательный перенос (интерференция), (объект экологии языка).

С точки зрения лингводидактики, проблематика межъязыковой омонимии это также сложный аспект. Цель сравнительного анализа в аспекте лингводидактики - определить в процессе перевода возможности трансформации языковых систем или установить степени близости отдельных элементов на родном и изучаемом языках как основу для подготовки материала к преподаванию иностранных языков.

Межъязыковая омонимия является проблемой не только для устных и письменных переводчиков, лингвистов, учителей и преподавателей иностранных языков, но и для обычных пользователей языка. В то же время можно предположить, что некоторые лексемы родственных языков перестроили свою семантическую структуру под влиянием межъязыковых отношений омонимического характера, которые вызывают интерференцию.

В конце 2019 года в чешском издательстве Tribun EU в контексте словацкой русистики был издан первый подобного рода Slovník rusko-slovenských medzijazykových hoтопу́m (Словарь русско-словацких межъязыковых омонимов). (В контексте чешской русистики см. словарь М. Чириковой и Н. Коничковой Zrádná slova v ruštině 2015 года издания и в контексте словацкого и украинского языкознания см. исторически первый словарь М. Чижмаровой и А. Яшковой Ukrajinsko-slovenská homonymia. Slovník ukrajinsko-slovenských medzijazykových homoným. Ukrajins'ko-slovac'ka omonimija. Slovnyk ukrajins'ko-slovac'kych mižmov-

Slavica Slovaca, roč. 38, 2003, s. 13-21; HORÁK, E.: Chorvátsko-slovinsko-slovenské lexikálne paralely. Slavica Slovaca, roč. 37, 2002, č. 1, s. 3-14; PANČÍKOVÁ, M.: Zradné slová v blizkych jazykoch. In: České, polské a slovenské jazykové a literární souvislosti. Sborník z mezinárodní konference uspořádané u př́ležitosti jubilea prof. Edvarda Lotka 20. února 2002. AUPO, Facultas Philologica. Philologica 78. Olomouc: Univerzita Palackého, 2003, s. 27-31; PANČÍKOVÁ, M.: Niekolko príkladov medzijazykovej homonymie - slovinčina, slovenčina. In: Mednarodni simpozij Obdobja. Ljubljana: Center za slovenščino kot drugi/tuji jezik pri oddelku za slovenistiko Filozofske fakultete, 2003, s. 495-500; VAŇKO, J.: Slovinsko-slovenská interlingválna homonymia. Slavia, roč. 73, 2004, sešit 1, s. 59-70; IVAŠINA, N. - RUDENKA, A. - JANOVEC, L.: Falešní prátelé překladatele v češtině a běloruštině. Praha: Univerzita Karlova v Praze, 2006; LACKOVÁ, M.: Interlingválne homonymá $v$ súčasných slovanských jazykoch. Žilina: EDIS - vydavatel'ské centrum Žilinskej univerzity, 2015 и др. 
nych omonimiv 2013 года издания). Slovník rusko-slovenských medzijazykových homoným нами считается единственным по обработке систематического обзора русско-словацких межъязыковых омонимов. Словарь является составной частью исследования научного грантового проекта KEGA o13UCM-4/2017 Vymedzovanie špecifík modelu „ruského sveta" $v$ ruskom jazyku, literatúre a kultúre (КЕГА о1зUСМ-4/2017 Определение специфики модели «русский мир» в русском языке, литературе и культуре) и финансированным из бюджета одноимённого проекта.

Данный словарь является результатом большого труда (не только) двух соавторов - Т. Григоряновой, кандидата филологических наук, доцента кафедры романских и славянских языков Факультета прикладных языков Экономического университета в Братиславе и Л. Гаярского, кандидата филологических наук кафедры русистики Философского факультета Университета Св. Кирилла и Мефодия в Трнаве. Во введении (с. 4) мы можем также узнать информацию от двух выше упоминаемых авторов, что «в отборе практического языкового материала из доступных русско-словачких словарей принимали участие: Катарина Чапичиова, Вероника Дргонёва, Лукаш Гаярский, Даниела Гласова, Михаела Митасова, Ивана Ширинцова, Никола Туранова, Люция Венгартова и Ивана Войнарова» (там же) с последующим вкладом студента-русиста Игоря Цинтулы, который, по словам авторов, «пополнил некоторые заглавные слова и добавил часть иллюстративного материала» (там же). Позволим выразить искреннюю благодарность и высоко оценить заинтересованность всех авторов, принимающих участие в создании словаря.

Рецензируемый нами словарь представляет собой первую попытку систематически осмыслить проблематику русско-словацкой омонимии с учётом лингводидактического аспекта. В словаре авторы практически разработали систематический обзор русско-словацких межъязыковых омонимов, так называемых ложных лексем (слов) или ложных друзей переводчика. При овладении русским языком данные лексемы часто являются осложнением, возникающим в результате интерференции генетически родственных языков. Кроме лингводидактического значения работы, являющейся отличным пособием в процессе обучения, подчёркиваем также её теоретическую важность в работе по устному и письменному переводу.

Т. Григорянова и Л.Гаярский адресуют словарь «прежде всего словачким студентам-русистам, но он может стать полезным учебным пособием для педагогов, переводчиков, лексикографов, а также и для широкой научной и непрофессиональной общественности» (c. 4). Собирая, обрабатывая и приводя 610 русско-словацких омонимических пар, основным замыслом авторов является представление омонимических пар, принадлежащих «к более широкому ядру 
русского и словащкого словарного запаса» (с. 6), что, на наш взгляд, полностью удалось осуществить.

Представленный словарь Т.Григоряновой и Л.Гаярского, являющийся первым изданием и отличающийся чёткостью композиции и продуманной структурой, состоит из нескольких составных частей - введение (с. 4), отбор заглавных слов и структура заглавного слова (с. 5-6), используемые сокращения (с. 7), список используемой литературы (с. 8), список заглавных слов (с. 9-21) и сам словарь (с. 23-126).

С точки зрения выбора и структуры заглавных слов, при их отборе авторы руководствовались самим типом словаря, т. е. основным критерием выбора слов для словаря межъязыковых омонимов были, согласно авторам, «те русские и словацкие пары слов, которые формально полностью или частично идентичны, но различаются по значению» (с. 5), в славянской лингвистической терминологии часто обозначаемые как falošní priatelia prekladatela (словацкий язык), јazyková falsiekvivalence, zdanlivé ekvivalenty, zrádná slova, falešní přátelé prekladatele, mezijazyková homonymie a paronymiе (чешский язык), ложные друзья переводчика, обманчивые межъязыковые сходства, межъязыковые паронимы, межъязыковые синонимы, межъязыковые полисемы, ложные или неполные лексические параллели, ложные эквиваленты, гетеронимы, ложные когнаты, псевдоинтернационализмы, апроксиманты (русский язык), міжмовна омонімія, хибні друзі перекладача, удавані друзі перекладача (украинский язык), фальшывыя сябры перекладчыка (белорусский язык), fałszywi przyjaciele, tautonyma, pułapki leksykalne, aprosymaty, aproxymatyzmy, pozorna ekwiwalencja (польский язык), lažni prijatelji, varljive besede, nepravi prijateli, medjezikovna homonimija in paronimija (словенский язык), апроксимация, лексикални успоредищи, апроксимати, неверни приятели на преводача, междуезикова омонимия (болгарский язык).

Мы разделяем точку зрения авторов, убедившихся на основе своего педагогического опыта, включить в словарь только пары слов, принадлежащие к одной и той же части слова (с некоторыми исключениями), а также с включением нескольких пар слов, напр. Опухоль - орисhlina «[...], которые вызывают обоснованные сомнения относительно того, являются ли они межъязыковыми омонимами, поскольку они более формально отличаются от других пар» (с. 5).

Русский язык, являющийся исходным языком, послужил для авторов основой в построении заглавных слов согласно русскому алфавиту. Оцениваем также не только решение авторов обработать каждое заглавное слово (напечатанное прописными буквами и выделенное жирным шрифтом) в отдельной таблице «ради большей наглядности» (там же), но и приведение в алфавитном порядке (также согласно русскому алфавиту) на с.9-21 списка всех встречающихся в словаре заглавных слов с указанием соответствующей страницы. Отметим, что 
читатель, таким образом, может быстро и легко найти данную омонимическую пару.

Что касается структуры каждой таблицы, то она состоит из четырёх столбцов, причём в первом авторы приводят сначала русское (авторы могли обозначить и словесное ударение) и ниже словацкое заглавное слово; во втором дают к каждому заглавному слову, жирным шрифтом выделенный соответствующий эквивалент на противоположном языке; в третьем приводят короткие коллокации с соответствующим эквивалентом перевода на противоположном языке, указанным в четвёртом столбце. Положительно можно оценить и то, что во втором столбце, авторы в случае необходимости, дают также стилистические пометы, указывающие на сферу использования слова (научный термин, юридический термин, медицинский термин, разговорное выражение, ботаника, география, переносное значение слова и т. д.), причём расшифровку всех помет объясняют в списке условных сокращений на с. 7 . Внутриязыковые омонимы, обозначенные верхним индексом, появляющиеся только в пределах одного языка, авторы приводят в отдельных строках друг под другом.

Для иллюстрации употребления данного русского заглавного слова в более широком контексте, Т. Григорянова и Л. Гаярский в последней строке приводят отдельные упрощенные и сокращённые синтаксические конструкции, которые «мы взяли в основном из Национального корпуса русского языка или сети Интернета» (с.5), на наш взгляд, вполне достаточные для определения и понимания правильного значения.

Подводя итог сказанному, можно сказать, что в лингвистике межъязыковая омонимия является сложным явлением, затрагивающим также различные сферы общества и вызывающим проблемы не только в преподавании иностранных языков, но и в повседневном общении.

Таким образом, в заключение хочется отметить, что в рецензируемом нами словаре авторы - Т. Григорянова и Л. Гаярский - проявили глубокое знание сути проблемы, большое мастерство и профессионализм в составлении такого типа словаря, а также продемонстрировали умение работать с корпусом и источниками. Следовательно, как нам кажется, их работа имеет большое не только практическое, но и теоретическое значение. Кроме этого, рецензируемый нами словарь Т.Григоряновой и Л.Гаярского, безусловно, будет полезным помощником не только в процессе обучения словацких учащихся, студентов, но и для учителей, преподавателей, переводчиков (устных и письменных), а также и для русскоговорящих учащихся, прибывших на территорию Словакии совсем недавно, или живущих здесь уже определённое время и желающих углубить свои знания словацкого языка. 
В целом, авторами - Т.Григоряновой и Л.Гаярским -, без сомнения, проделана большая и серьёзная работа, заслуживающая оценки par excellence.

Ян Галло

\section{Библиография:}

BARTÁKOVÁ, J.: K zradnostiam v blizzkopríbuzných jazykoch. In: ŠLOSAR, D. (red.): Sborník prací Filozofické fakulty brněnské univerzity. Brno: Masarykova univerzita, 1998, S. 151-159.

BUFFA, F.: O formálnych polsko-slovenských lexikálnych rozdieloch. Slavica Slovaca, roč. 37, 2002, č. 2, s. 97-106. ISSN 0037-6787.

CSAPÁK, R.: Medzijazyková homonymia v spisovnej slovenčine a bulharčine ako lexikologický problém. In: CHOVANEC, M. (ed.): Zborník zo 7. študentskej vedeckej konferencie. Prešov: Filozofická fakulta Prešovskej univerzity v Prešove, 2012, s. 808-813.

CSIRIKOVÁ, M. - KONÍČKOVÁ, N.: Zrádná slova v ruštině (Slovník rusko-českých homonym). Praha: LEDA, 2015. 264 s. ISBN 978-80-7335-405-3.

ČIŽMÁROVÁ, M. - JAŠKOVÁ, A.: Ukrajinsko-slovenská homonymia. Slovník ukrajinsko-slovenských medzijazykových homoným. Ukrajins'ko-slovac'ka omonimija. Slovnyk ukrajins'ko-slovac'kych mižmovnych omonimiv. Prešov: Filozofická fakulta Prešovskej univerzity v Prešove, 2013. 273 s. ISBN 978-80-555-0759-0.

GRIGORJANOVÁ, T. - GAJARSKÝ, L.: Slovník rusko-slovenských medzijazykových homoným. Brno: Tribun EU, 2019. 127 s. ISBN 978-80-263-1544-5.

HLADKÝ, J.: Zrádná slova v angličtině. Praha: Státní pedagogické nakladatelství, 1990. 187 s. ISBN 80-04-21834-2.

HORÁK, E.: Chorvátsko-slovinsko-slovenské lexikálne paralely. Slavica Slovaca, roč. 37, 2002, č. 1, s. 3-14. ISSN 0037-6787.

HORÁKOVÁ, R.: Interlingválne homonymá ako lexikografický problém. Slavica Slovaca, roč. 38, 2003, s. 13-21. ISSN 0037-6787.

HORÁKOVÁ, R.: Medzijazyková homonymia pri geneticky príbuzných jazykoch. Filologická revue, roč. 2, 1999, č. 4, s. 52-56. ISSN 1335-3624.

HORÁKOVÁ, R.: Slovinsko-slovenská homonymia z konfrontačného hladiska. In: PANČÍKOVÁ, M. (ed.): Philologica LIII. Zborník Filozofickej fakulty Univerzity Komenského v Bratislave, 2001, s. 175-180. ISBN 80-223-1610-5.

IVAŠINA, N. - RUDENKA, A. - JANOVEC, L.: Falešní prátelé překladatele v češtině a běloruštině. Praha: Univerzita Karlova v Praze, 2006. 122 s. ISBN 80-7290-275-X. 
LACKOVÁ, M.: Interlingválne homonymá v súčasných slovanských jazykoch. Žilina: EDIS - vydavatel'ské centrum Žilinskej univerzity, 2015. 113 s. ISBN 978-80-554$-1041-8$.

LOTKO, E.: Zrádná slova v polštině a češtině. Olomouc: Filozofická fakulta Univerzity Palackého, 1987. $53 \mathrm{~s}$.

ORGOŇOVÁ, O.: Falošní priatelia (faux-amis) v jazykových kontaktoch slovenčiny $s$ francúzštinou. In: MISTRÍK, J. (red.): Studia Academica Slovaca 2o. Prednášky XXVII. letného seminára slovenského jazyka a kultúry. Bratislava: Alfa, 1991, s. 193-212.

PANČÍKOVÁ, M.: Niekolko príkladov medzijazykovej homonymie - slovinčina, slovenčina. In: Mednarodni simpozij Obdobja. Ljubljana: Center za slovenščino kot drugi/tuji jezik pri oddelku za slovenistiko Filozofske fakultete, 2003, s. 495-500.

PANČÍKOVÁ, M.: Zradné slová v blízkych jazykoch. In: České, polské a slovenské jazykové a literární souvislosti. Sborník z mezinárodní konference uspořádané u př́ležitosti jubilea prof. Edvarda Lotka 20. února 2002. AUPO, Facultas Philologica. Philologica 78. Olomouc: Univerzita Palackého, 2003, s. 27-31. ISBN 80-244-0628-4. TRUP, L.: Problematika „zradných slov" $v$ slovenčine a španielčine. Slovenská reč, roč. 46 , 1981, č. 4, s. 212-221. Bez ISSN.

VAŇKO, J.: Slovinsko-slovenská interlingválna homonymia. Slavia, roč. 73, 2004, sešit 1, s. 59-70. ISSN 0037-6736.

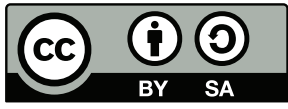

This work can be used in accordance with the Creative Commons BY-SA 4.0 International license terms and conditions (<https://creativecommons.org/licenses/by-sa/4.0/legalcode>). This does not apply to works or elements (such as images or photographs) that are used in the work under a contractual license or exception or limitation to relevant rights.

\section{https://doi.org/10.5817/OS2020-2-8}

\section{Stránky z bulharské literatury}

ПАЦЕВА, М., РУНЕВСКА, Е., ПАНОВА, Ст. (съст.) Страници от българската литература. Кратка учебна антология. София: Софийски университет „Св. Климент Охридски“, 2019, 235 с., ISBN 978-619-7433-21-о.

Stránky z bulharské literatury představuje antologii vybraných děl bulharské literatury určenou studijním účelům. Posloužit by měla především bulharským a zahraničním studentům bulharistiky, jistě ji ale přivítá každý, kdo projevuje zájem o bulharskou literaturu. Antologii sestavily odbornice ze Sofijské univerzity sv. 